\section{1. 半球切除術の適応と術式}

$$
\begin{aligned}
& \text { 東京都立神経病院脳神経外科 } \\
& \text { 清水 弘之 }
\end{aligned}
$$

難治てんかんの手術は，切除手術と遮断手術の二つに大別 される.切除手術としては, 病巣切除術, 皮質焦点切除術, 脳葉切除術などがあげられる。遮断手術としては，MST (軟膜下皮質多切除), 脳梁離断術, 線維切断による半球切除 術などが代表的である. 物理的半球切除術は, 術後数年を経 過して superficial cerebral hemosiderosisなどの重篤な合 併症をきたすことから，1980年代以降, 機能的半球切除術 にとって代わってきた。半球切除術の対象としては, 病巣が 片側非優位半球全体に及び，患側に対応する片麻痺，半側視 野欠損が存在するのが理想的である。しかし，乳幼児期に片 側半球病変が発見され, 難治てんかんを伴う場合は, 脳の可 塑性に富む早期に手術を施行する方が精神運動発達に好影響 を与える。われわれの施行している線維切断を主体とする手 術手技をビデオを交えて提示する.

\section{2. てんかんの外科：切除外科の現状}

国立療養所静岡東病院（てんかんセンター）
脳神経外科
三原 忠絋

画像診断の進歩により，臨床発作と密接な関係にある領域 が視覚的に表現され，てんかんの外科治療が一段と身近なも のになった。演者らは 1983 年より，もつぱら切除外科を行 い, 1998 年末までに, 側頭葉の手術を 266 例, 側頭葉以外 の脳葉の手術を 71 例, 経験した.この内の 179 例は慢性頭 蓋内脳波記録を経由した。術後 2 年以上が経過した症例の成 績は, Engelの class-I (発作消失群) についてみると, 側 頭葉の手術で約 80\%であった. しかし, 側頭葉以外の手術 では $60 \%$ に達しなかった。

側頭葉焦点の動態，内側側頭葉てんかんの手術，新皮質焦 点の同定, 小児の外科治療, 術後成績の評価, などに言及し ながら，演者らの経験を紹介したい。

\section{Surgical Technique of Selective Amygdalo- hippocampectomy}

Department of Neurosurgery, Marmara University School of Medicine

Ugur Türe, M.D.

The mediobasal portion of the temporal lobe is formed of mesocortex (parahippocampal gyrus) and allocortex (amygdala, piriform cortex, and hippocampus). These are part of the limbic system, which is crucial to all aspects of memory, learning, and emotion. The exact functional aspects and neural connections of the temporal lobe remain unclear and the success of surgical procedures depends on reduction the amount of damage inflicted.

A transsylvian selective amygdalohippocampectomy was introduced by Yasargil as a viable alternative to the standard temporal lobectomy for the treatment of intractable epilepsy of medial temporal lobe origin. Through a transsylvian approach and a small incision in the inferior peri-insular sulcus at the level of the limen insula, selective removal of the amygdala and hippocampus can be accomplished. Transsylvian selective amygdalohippocampectomy does not result in the lateral cortical damage that is associated with other resective techniques of the temporal lobe. This procedure can be accomplished without causing postoperative neurologic deficit, and assures an improved neuropsychologic and psychosocial outcome. Because of its complex anatomic features and its close relationship with vital neural and vascular structures, knowledge of the microsurgical anatomy of the medial temporal lobe and implementation of precise microsurgical technique are essential to achieving success in selective removal of the amygdala and hippocampus. 